\title{
Alternatif Perencanaan Abutment dan Oprit Fly Over Kandangan, Surabaya, Jawa Timur
}

\author{
Pungky Aditya Saputra, Suwarno, dan Trihanyndio Rendy Satrya \\ Departemen Teknik Sipil, Institut Teknologi Sepuluh Nopember (ITS) \\ Corresponding Author: trendysatrya@gmail.com
}

\begin{tabular}{l}
\hline ARTIKEL INFO \\
\hline Informasi Artikel \\
Artikel masuk: \\
Artikel revisi : \\
Artikel diterima: \\
\end{tabular}

\section{Kata Kunci}

Fly over, Oprit, Timbunan bersisi miring, Timbunan bersisi tegak, Geotextile, Geogrid, Sheet-pile, Keystone wall, Micropile, Abutment.

\begin{abstract}
ABSTRAK
Kota Surabaya merupakan salah satu kota besar di Indonesia yang selalu bermasalah dalam bidang transportasi terutama kemacetan. Adanya pembangunan fly over yang melintasi jalur trek ganda kereta api Stasiun Benowo - Stasiun Kandangan KM 219+958 yang terletak di Desa Kandangan ini termasuk salah satu solusi untuk mengatasi kemacetan di Surabaya barat khususnya di daerah Kandangan dan sebagai jalur alternatif menuju Gresik. Pada penulisan studi ini penulis memodifikasi desain awal fly over Kandangan yang awalnya dengan konstruksi pilar disetiap bentangnya, dirubah menjadi timbunan tanah dengan alasan biaya timbunan lebih ekonomis daripada konstruksi pilar jembatan. Direncanakan alternatif bentuk timbunan` oprit serta perkuatan tanah timbunan dan perbaikan tanah dasarnya. Dua alternatif bentuk timbunan yang dibandingkan yaitu timbunan bersisi tegak dan bersisi miring. Dalam perencanaan perkuatan oprit bersisi tegak akan dibandingkan dua alternatif perkuatan antara lain: geotextile wall reinforcement kombinasi dengan flat sheet-pile concrete, dan geogrid wall reinforcement kombinasi dengan keystone wall. Sedangkan untuk perencanaan perkuatan oprit bersisi miring akan dibandingkan dua alternatif perkuatan antara lain: geotextile slope reinforcement dan cerucuk berupa micropile beton. Abutment direncanakan dengan kestabilan konstruksi harus ditinjau terhadap pengaruh gaya-gaya eksternal maupun terhadap gayagaya internal yang dapat menyebabkan pecahnya konstruksi. Apabila abutment tidak memenuhi maka daya dukungnya harus direncanakan pondasi dalam berupa tiang pancang. Hasil dari perhitungan total biaya konstruksi pada perencanaan oprit didapatkan diantaranya untuk oprit bersisi tegak dengan alternatif perkuatan geotextile kombinasi sheet-pile adalah Rp. 86.280.857.674,34 dan untuk alternatif perkuatan geogrids kombinasi keystone-wall adalah Rp. 73.797.613.851,84. Sedangkan untuk oprit bersisi miring dengan alternatif perkuatan geotextile adalah $\mathrm{Rp}$. 103.183.365.174,93 dan untuk alternatif perkuatan micropile adalah $\mathrm{Rp}$. 134.243.009.394,93. Maka dipilih alternatif timbunan dan perkuatan yang paling efektif dari segi biaya, pelaksanaan, dan hemat ruang sehingga oprit bersisi tegak dengan perkuatan geogrids kombinasi keystone-wall adalah yang paling sesuai. Sedangkan untuk abutment direncanakan dengan lebar melintang 32,725 $\mathrm{m}$ dan tinggi total 12,530 m. Dimensi pilecap $32,725 \mathrm{~m} \times 6,5 \mathrm{~m}$. Pondasi dalam dipakai tiang pancang PC Spun Pile diameter $60 \mathrm{~cm}$ berjumlah 84 buah dengan dipancang kedalaman 42 $\mathrm{m}$ dari OGL.
\end{abstract}

\section{PENDAHULUAN}

Kota Surabaya merupakan salah satu kota besar di Indonesia yang selalu bermasalah dalam bidang transportasi terutama kemacetan. Khususnya di daerah Kandangan sebuah kelurahan di wilayah Kecamatan Benowo, Surabaya Barat kemacetan sangat rentan terjadi pada saat jam kerja.

Salah satu faktor penghambat kelancaran lalu lintas yang mengakibatkan kemacetan adalah dikarenakan
Jalan Raya Kandangan tersebut melintasi jalur kereta api Stasiun Benowo - Stasiun Kandangan untuk berhubung dengan Jalan Kauman Surabaya. Dengan kondisi seperti itu, kemacetan panjang disaat kereta api akan melintas pada titik perpotongan dengan jalan raya tersebut sangat rentan terjadi.

Oleh karena permasalahan tersebut, diperlukan langkah pembangunan infrastruktur yang mendukung untuk mengatasi permasalahan kemacetan. Adanya pembangunan fly over yang melintasi jalur trek ganda 
kereta api Stasiun Benowo - Stasiun Kandangan KM 219+958 yang terletak di Desa Kandangan ini termasuk salah satu solusi untuk mengatasi kemacetan di Surabaya barat khususnya di daerah Kandangan. Titik lokasi rencana pembangunan fly over kandangan seperti dijelaskan pada Gambar 1:

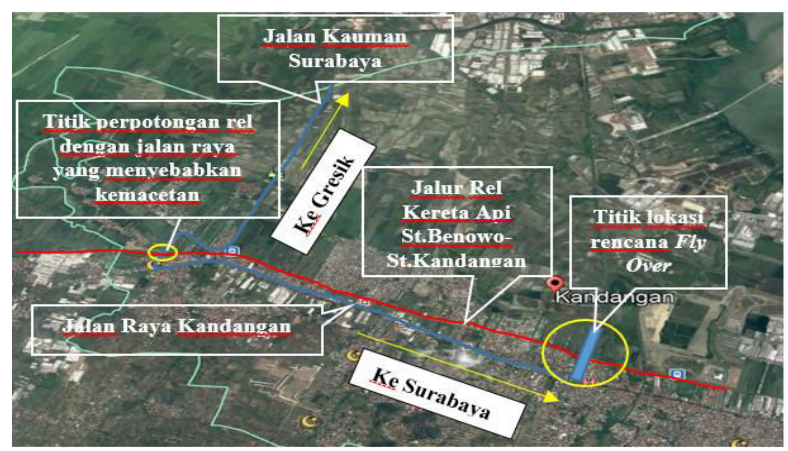

Gambar 1. Titik Lokasi Fly Over Kandangan Surabaya Barat.

Fly over Kandangan semula direncanakan 4 lajur-2 arah dibatasi median dengan lebar total 20 meter. Akan tetapi dikarenakan adanya rencana pengembangan area perumahan diwilayah Kandangan dan meningkatnya angka pertumbuhan lalu lintas, sehingga direncanakan ulang fly over dengan lebar total 30 meter dibatasi median dengan masing-masing lebar 15 meter. Oleh karena perubahan perencanaan yang semula dengan lebar total 20 meter dirubah menjadi lebar total 30 meter, maka diperlukan perencanaan ulang pondasi dan abutment yang baru akibat perubahan beban rencana. Sketsa perencanaan awal fly over Kandangan dengan lebar total 20 meter, panjang per-bentang jembatan 30 meter, panjang horizontal jembatan 272 meter, dan panjang oprit jembatan 40 meter.

Dalam penulisan studi ini abutment direncanakan harus mampu menahan beban-beban pada jembatan. Kestabilan konstruksi harus ditinjau terhadap pengaruh gaya-gaya eksternal dan gaya-gaya internal yang dapat menyebabkan pecahnya konstruksi. Apabila daya dukung tanah yang terdapat dibawah abutment tidak memenuhi maka daya dukungnya harus ditambah dengan pondasi dalam. Sementara itu dikarenakan keterbatasan biaya dan luas ketersediaan lahan dari perencanaan yang lama, maka oprit direncanakan dengan membandingkan antara perencanaan timbunan bersisi tegak dan bersisi miring atau bebas serta perhitungan alternatif perkuatan yang dibutuhkan.

\section{METODE PENELITIAN}

Langkah-langkah utama yang digunakan dalam penelitian dijelaskan bagan pada Gambar 2 .

\section{PEMBAHASAN}

\section{A. Data Parameter Tanah Dasar \& Tanah Timbunan}

Data parameter tanah yang akan dijadikan acuan untuk perencanaan dalam studi ini digunakan data sekunder berdasarkan pengujian laboratorium dan lapangan.

Data rencana timbunan tanah oprit terdiri dari fisik material timbunan serta dimensi timbunan per titik zona dan stationing tertinjau. Sifat fisik material timbuan direncana yaitu:

Jenis tanah : Pasir sirtu

$$
\begin{aligned}
\gamma \mathrm{t} & : 1,8 \mathrm{t} / \mathrm{m}^{3} \\
\phi & : 30^{\circ} \\
\mathrm{Cu} & : 0 \mathrm{t} / \mathrm{m}^{2}
\end{aligned}
$$

Satu sisi Timbunan oprit yang direncanakan ditinjau menjadi 4 zoning dan 5 potongan dimensi diantaranya sebagai berikut:

a. Zoning A: potongan 5-5, Tinggi timbunan $0 \mathrm{~m} \mathrm{~s} / \mathrm{d} 3$ $\mathrm{m}$, Stasioning 0+000 s/d 0+075.

b. Zoning B: potongan 4-4, Tinggi timbunan $3 \mathrm{~m} \mathrm{~s} / \mathrm{d} 6$ $\mathrm{m}$, Stasioning 0+075 s/d 0+150.

c. Zoning C: potongan 3-3, Tinggi timbunan $6 \mathrm{~m} \mathrm{~s} / \mathrm{d} 9$ $\mathrm{m}$, Stasioning 0+150 s/d 0+225.

d. Zoning D: potongan 2-2, Tinggi timbunan $9 \mathrm{~m} \mathrm{~s} / \mathrm{d}$ $10.459 \mathrm{~m}$, Stasioning $0+225 \mathrm{~s} / \mathrm{d} 0+263$.

e. Zoning D: potongan 1-1 (didalam wing-wall abutment), Tinggi timbunan $10.459 \mathrm{~m} \mathrm{~s} / \mathrm{d} 10.659 \mathrm{~m}$, Stasioning 0+263 s/d 0+267.

\section{B. Perencanaan Alternatif Oprit Berisi Tegak}

- Perhitungan H-Initial Oprit Berisi Tegak

Digunakan persamaan untuk perhitungan $\mathrm{H}$-initial \& $\mathrm{H}$-final timbunan sebagai berikut:

$\mathrm{H}$ initial $=\left(\mathrm{Q}_{\text {timbunan }}+\left(S c_{\text {timbunan }} \mathrm{x} \gamma_{\mathrm{w}}\right)\right) / \gamma_{\text {timbunan }}$

$\mathrm{H}$ final $=\left(\mathrm{H}\right.$ initial $\left.-S c_{\text {timbunan }}-S c_{\text {pavement }}-\mathrm{H}_{\text {bongkar traffic }}\right)$

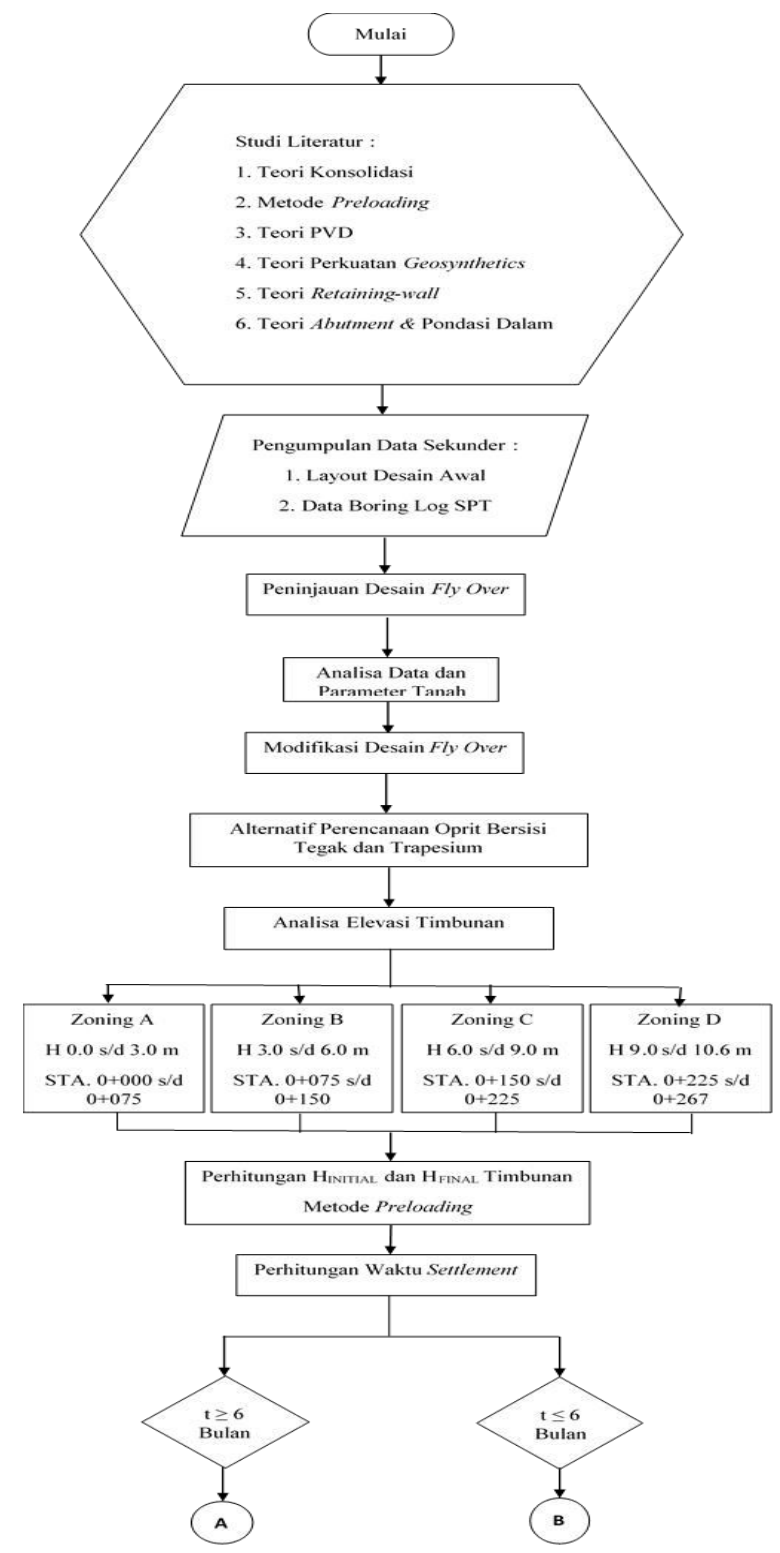




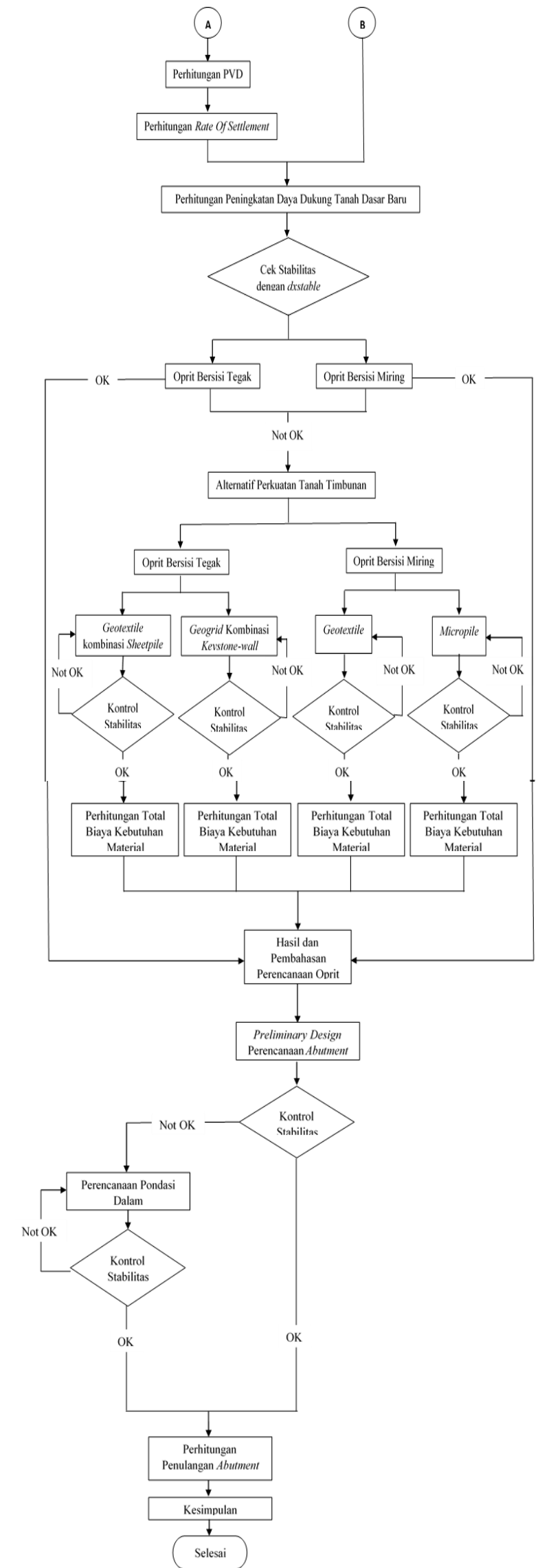

Gambar 2. Bagan Alir Pengerjaan Studi.

\section{$+\mathrm{H}$ pavement}

Untuk mendapatkan $\mathrm{H}$-final rencana timbunan oprit bersisi tegak, telah didapatkan $\mathrm{H}$-initial dari perhitungan seperti yang ditunjukkan pada Tabel 1:

Tabel 1. Rekap Perhitungan H-Timbunan Oprit Berisi Tegak

\begin{tabular}{lccc}
\hline Zona A (pot. 5-5) & 3 & 3,6353 & 0,635 \\
Zona B (pot. 4-4) & 6 & 7,5321 & 1,532 \\
Zona C (pot. 3-3) & 9 & 10,9258 & 1,926 \\
Zona D (pot. 2-2) & 10,459 & 12,5374 & 2,078 \\
Zona D (pot. 1-1) & 10,659 & 12,7568 & 2,098 \\
didalam wing-wall & & \\
\hline
\end{tabular}

- Perhitungan PVD \& PHD untuk Oprit Berisi Tegak

Berdasarkan perhitungan didapatkan harga $C_{v}$ gabungan rata-rata adalah $=0.0001470699 \mathrm{~cm}^{2} / \mathrm{s}$, atau $0.0088947904 \mathrm{~m}^{2} / \mathrm{minggu}$, atau $0,4637997836 \mathrm{~m}^{2} /$ tahun.

Perhitungan waktu konsolidasi dengan diharapkan derajat konsolidasi $\mathrm{U}_{\mathrm{v}}=90 \%$, maka didapatkan variasi faktor waktu $\left(\mathrm{T}_{\mathrm{v}}\right)=0,848$. Maka dapat dihitung waktu konsolidasi alami tanpa ada metode percepatan pemampatan sebagai berikut:

$\mathrm{t}=\left(\mathrm{T}_{90 \%} \times \mathrm{H}_{\mathrm{dr}}{ }^{2}\right) / C_{v}=\left(0,848 \times 121^{2}\right) / 0,463 \mathrm{~m}^{2} / \mathrm{tahun}$ $\mathrm{t}=222$ tahun $=11536$ minggu, maka $\mathrm{t}>6$ bulan,

Maka waktu konsolidasi alami tanpa ada metode percepatan pemampatan untuk menghilangkan consolidation settlement sangat lama yaitu 222 tahun.

Sehingga diputuskan untuk mempercepat proses konsolidasi dan Mempercepat peningkatan daya dukung tanah dasar diperlukan PVD serta PHD untuk pengalir air pori dari PVD. Dengan perhitungan digunakan persamaan:

$$
t=\left(\frac{D^{2}}{8 \cdot C h}\right) \cdot(2 \cdot F(n)) \cdot \ln \left(\frac{1}{1-U h}\right)
$$

Dengan hasil perhitungan installasi PVD sebagai berikut:

Alternatif timbunan bersisi tegak

Pola pemasangan PVD: segi empat

Spasi pemasangan $\quad: 0,8 \mathrm{~m}$

Kadalaman pancang : $11 \mathrm{~m}$ (very soft to medium stiff soil)

Jumlah titik PVD : 2 x 13360 titik (untuk 2 oprit)

Jumlah baris PHD : $2 \times 334$ baris melintang (untuk 2 oprit)

- Kestabilan Timbunan Oprit Berisi Tegak Setelah

Metode Preloading

Akibat adanya penimbunan bertahap (preloading) tentunya tanah akan mengalami pemampatan. Oleh akibat adanya pemampatan itu maka dapat dianalisis berdasarkan kestabilan lereng dengan software DXSTABLE oleh juga karena peningkatan daya dukung tanah dasar setelah selesai masa penimbunan $\mathrm{H}$-initial. Untuk kestabilan timbunan oprit bersisi tegak diperoleh hasil seperti yang ditunjukkan pada Tabel 2:

Tabel 2. Rekap Kestabilan Timbunan Oprit Berisi Tegak

\begin{tabular}{|c|c|c|c|c|}
\hline Zoning Oprit & $\begin{array}{c}\text { SF } \\
\text { eksisting } \\
\text { min. }\end{array}$ & Cek & $\begin{array}{c}\text { SF } \\
\text { Renc } \\
\text { ana }\end{array}$ & Ket. \\
\hline Zona A (pot. 5-5) & 1.167 & $<$ & 1.25 & $\begin{array}{c}\text { Butuh } \\
\text { Perkuatan }\end{array}$ \\
\hline Zona B (pot. 4-4) & 0.884 & $<$ & 1.25 & $\begin{array}{c}\text { Butuh } \\
\text { Perkuatan }\end{array}$ \\
\hline Zona C (pot. 3-3) & 0.856 & $<$ & 1.25 & $\begin{array}{c}\text { Butuh } \\
\text { Perkuatan }\end{array}$ \\
\hline Zona D (pot. 2-2) & 0.853 & $<$ & 1.25 & $\begin{array}{l}\text { Butuh } \\
\text { Perkuatan }\end{array}$ \\
\hline $\begin{array}{l}\text { Zona D (pot. 1-1) } \\
\text { didalam wing- } \\
\text { wall }\end{array}$ & 0.83 & $<$ & 1.25 & $\begin{array}{c}\text { Butuh } \\
\text { Perkuatan }\end{array}$ \\
\hline
\end{tabular}


- Perkuatan Timbunan Oprit Berisi Tegak (Alternatif Geotextile kombinasi Flat Sheet-pile)

Perhitungan kebutuhan geotextile digunakan persamaan sebagai berikut:

- $S v=\frac{T_{\text {Allow }}}{S F \times \sigma H_{\text {totalz }}} ;$ dengan $\mathrm{Sv}$ pakai $<\mathrm{Sv}$

Hitungan.

- $L r=(H-Z) \times \tan \left(45-\frac{\phi}{2}\right)$; dengan $\operatorname{Lr}$ pakai $>\mathrm{Lr}$ output $d x$ stable $>$ Lr Hitungan.

$$
\begin{aligned}
-L e=\frac{S v \cdot \sigma h \cdot S F}{2 \cdot[C+\sigma v \cdot \tan \delta]} ; \\
\text { dengan jika }<1 \mathrm{~m}, \text { maka } \approx 1 \mathrm{~m} . \\
\text { - } L o=\frac{S v \cdot \sigma h \cdot S F}{4 \cdot[C+\sigma v \cdot \tan \delta]} ; \\
\text { dengan jika }<1 \mathrm{~m} \mathrm{maka} \approx 1 \mathrm{~m} .
\end{aligned}
$$

Kestabilan geotextile juga dikontrol terhadap 3 kondisi dengan persamaan sebagai berikut:

- Eksternal Stability:

$$
\mathrm{SF}=\frac{\Sigma W \cdot x+\Sigma P a \cdot \sin \delta x}{\Sigma P a \cdot \cos \delta x}>1,5
$$

- Kontrol Geser:

$$
S F=\frac{C+\left(\left(\frac{\Sigma W+\Sigma P a \cdot \sin \delta}{L}\right) \times \tan \delta\right)}{\left(\frac{\Sigma P a \cdot \cos \delta}{L}\right)}>3
$$

$$
\text { - kontrol bearing capacity failure }
$$

\begin{tabular}{|c|c|c|c|c|}
\hline Zoning Oprit & $\begin{array}{l}\text { H Final } \\
(\mathrm{m})\end{array}$ & $\begin{array}{c}\mathrm{H} \text { initial } \\
(\mathrm{m})\end{array}$ & $\begin{array}{c}\text { Reinforc } \\
\text { ement }\end{array}$ & $\begin{array}{l}\text { Total } \\
\text { Layer }\end{array}$ \\
\hline Zona A (pot. 5-5) & 3 & 3.635 & $\begin{array}{l}\mathrm{GW}^{*} \\
200 / 45\end{array}$ & $\begin{array}{c}14 \\
\text { layer }\end{array}$ \\
\hline Zona B (pot. 4-4) & 6 & 7.532 & $\begin{array}{c}\text { GW } \\
200 / 45\end{array}$ & $\begin{array}{c}30 \\
\text { layer }\end{array}$ \\
\hline Zona C (pot. 3-3) & 9 & 10.926 & $\begin{array}{c}\text { GW } \\
200 / 45\end{array}$ & $\begin{array}{c}32 \\
\text { layer }\end{array}$ \\
\hline Zona D (pot. 2-2) & 10.459 & 12.537 & $\begin{array}{c}\mathrm{GW} \\
200 / 45\end{array}$ & $\begin{array}{c}38 \\
\text { layer }\end{array}$ \\
\hline $\begin{array}{l}\text { Zona D (pot. 1-1) } \\
\text { didalam wing-wall }\end{array}$ & 10.659 & 12.757 & $\begin{array}{c}\text { GW } \\
200 / 45\end{array}$ & $\begin{array}{c}39 \\
\text { layer }\end{array}$ \\
\hline
\end{tabular}

Didapatkan hasil dari perhitungan yang aman untuk masing-masing zoning seperti yang ditunjukkan pada Tabel 3:

Tabel 3. Rekap Kebutuhan Geotextile Oprit berisi Tegak

Karena sheet pile yang direncanakan tidak menerima beban sama sekali dan hanya berfungsi sebagai penutup sisi timbunan, maka direncanakan kedalaman tanam sheet pile sebesar $4 \mathrm{~m}$ untuk ketinggian oprit $0 \mathrm{~m}$ hingga 10,459 m. Direncanakan pula besi penahan berjarak setiap $2 \mathrm{~m}$ untuk berjaga-jaga apabila ada gaya horizontal yang tidak diinginkan.

- Kontrol bearing capacity failure ;

Dengan Q ijin adalah dihitung berdasarkan daya dukung tiang sheetpile metode Mayerhoff dan Bazaraa. Flat Sheet-pile diasumsi sebagai tiang diameter $32 \mathrm{~cm}$ dengan kedalaman $4 \mathrm{~m}$, didapatkan $\mathrm{Q}$ ijin $=\mathrm{Q}$ ujung + $\sum \mathrm{Rsi}=37,21$ ton.
Dengan V/A = total length $\mathrm{x}$ unit weight $=14,459 \mathrm{~m} \mathrm{x}$ 0,4 ton $/ \mathrm{m}=5,7836$ ton, dengan sheet-pile diasumsi tidak menerima gaya horizontal dari tanah timbunan maka $\mathrm{M} / \mathrm{W}=0$. Maka didapatkan $S F=\frac{37,21}{5,7836+0}=6,433>3 \ldots$ OK! maka aman terhadap bearing capacity.

- Periksa terhadap gaya lateral gempa

Dimana moment crack sheet-pile harus mampu melawan momen gaya geser seismic.

$\mathrm{SF}=$ moment crack Sheet Pile / moment seismic $>1,5$.

Dengan diasumsi koefisien dasar gempa $(\mathrm{Cs})=8 \% \mathrm{x}$ berat SP.

$\mathrm{F}$ seismic $=\mathrm{Cs} \mathrm{x}$ unit weight $\mathrm{x}$ HSP from top soil $=8 \% \mathrm{x}$ 0,4 ton $/ \mathrm{m} \times 10,459 \mathrm{~m}=0,334$ ton

$\mathrm{M}$ seismic $=\mathrm{F}$ seismic $\times$ HSP $=0,334$ ton $\times 10,459 \mathrm{~m}=$ 3,5 ton.m

$\mathrm{M}$ crack sheet pile $=6,05$ ton. $\mathrm{m}$

$\mathrm{SF}=6,05 / 3,5=1,728>1,5$ aman dari gaya lateral gempa.

- Perkuatan Timbunan Oprit Berisi Tegak (Alternatif

Perkuatan Geogrids kombinasi Keystone-wall)

\begin{tabular}{|c|c|c|c|c|}
\hline Zoning Oprit & $\begin{array}{l}\text { H Final } \\
(\mathrm{m})\end{array}$ & $\begin{array}{l}\mathrm{H} \text { initial } \\
(\mathrm{m})\end{array}$ & $\begin{array}{c}\text { Reinforc } \\
\text { ement }\end{array}$ & $\begin{array}{l}\text { Total } \\
\text { Layer }\end{array}$ \\
\hline Zona A (pot. 5-5) & 3 & 3.635 & $\begin{array}{c}\text { GU* } \\
\text { TT-160 }\end{array}$ & 7 layer \\
\hline Zona B (pot. 4-4) & 6 & 7.532 & $\begin{array}{c}\text { GU } \\
\text { TT-160 }\end{array}$ & $\begin{array}{c}20 \\
\text { layer }\end{array}$ \\
\hline Zona C (pot. 3-3) & 9 & 10.926 & $\begin{array}{c}\text { GU } \\
\text { TT-160 }\end{array}$ & $\begin{array}{c}37 \\
\text { layer }\end{array}$ \\
\hline Zona D (pot. 2-2) & 10.459 & 12.537 & $\begin{array}{c}\text { GU } \\
\text { TT-160 }\end{array}$ & $\begin{array}{c}45 \\
\text { layer }\end{array}$ \\
\hline $\begin{array}{l}\text { Zona D (pot. 1-1) } \\
\text { didalam wing-wall }\end{array}$ & 10.659 & 12.757 & $\begin{array}{c}\text { GU } \\
\text { TT-160 }\end{array}$ & $\begin{array}{c}45 \\
\text { layer }\end{array}$ \\
\hline
\end{tabular}

Perhitungan kebutuhan geogrids digunakan persamaan yang sama dengan perhitungan geotextile untuk timbunan bersisi tegak. Diantaranya perhitungan Sv, Lr, Le, Lo dan kontrol stabilitasnya. Didapatkan hasil perhitungan untuk masing-masing zoning seperti yang ditunjukkan pada Tabel 4:

Tabel 4. Rekap Kebutuhan Geotextile Oprit berisi Tegak

Keystone-wall yang direncanakan tidak menerima gaya horisontal timbunan tanah karena semua gaya horisontal telah diterima oleh geogrids. Kontrol bearing capacity failure ;

Dengan Q ijin dihitung berdasarkan daya dukung pondasi dangkal metode Terzaghi. Keystone diasumsi sebagai model pondasi dangkal dengan kedalaman $4 \mathrm{~m}$.

Didapatkan $S F=\frac{14,518}{4,771+0}=3,042>3 \ldots O K !$ maka aman terhadap bearing capacity.

\section{Perencanaan Alternatif Oprit Berisi Miring}

Digunakan persamaan untuk perhitungan $\mathrm{H}$-initial \& $\mathrm{H}$-final sama seperti pada perhitungan oprit bersisi tegak. Untuk $\mathrm{H}$-final rencana timbunan oprit bersisi miring, didapatkan $\mathrm{H}$-initial dari perhitungan seperti yang ditunjukkan pada Tabel 5:

Tabel 5. Rekap Perhitungan H-Timbunan Oprit Berisi Miring

\begin{tabular}{rccc}
\hline Zoning Oprit & H Final $(\mathrm{m})$ & H Initial $(\mathrm{m})$ & $\Delta \mathrm{H}(\mathrm{m})$ \\
\hline Zona A (pot. 5-5) & 3 & 4.4569 & 1.457 \\
Zona B (pot. 4-4) & 6 & 8.3042 & 2.304 \\
Zona C (pot. 3-3) & 9 & 11.7566 & 2.757 \\
Zona D (pot. 2-2) & 10,459 & 13.3901 & 2.931
\end{tabular}


Zona D (pot. 1-1) didalam wing-wall

10,659

12.7568

2.098

- Perhitungan PVD \& PHD untuk Oprit Berisi Miring Berdasarkan perhitungan yang sama seperti pada perhitungan PVD untuk oprit bersisi tegak maka didapatkan dengan hasil perhitungan installasi PVD sebagai berikut:

Alternatif timbunan bersisi miring

Pola pemasangan PVD: segi empat

Spasi pemasangan $: 0,8 \mathrm{~m}$

Kadalaman pancang : $11 \mathrm{~m}$ (very soft to medium stiff soil)

Jumlah titik PVD: 2 x 20040 titik (untuk 2 oprit)

Jumlah baris PHD: 2 x 334 baris melintang (untuk 2 oprit)

Akibat adanya penimbunan bertahap (preloading) tentunya tanah akan mengalami pemampatan. Oleh akibat adanya pemampatan itu maka dapat dianalisis berdasarkan kestabilan lereng dengan software DXSTABLE. Untuk kestabilan timbunan oprit bersisi miring diperoleh hasil seperti yang ditunjukkan pada Tabel 6:

Tabel 6. Rekap Kestabilan Timbunan Oprit Berisi Miring

\begin{tabular}{|c|c|c|c|c|}
\hline Zoning Oprit & $\begin{array}{c}\text { SF } \\
\text { eksisting } \\
\text { min. }\end{array}$ & Cek & $\begin{array}{c}\text { SF } \\
\text { Renc } \\
\text { ana } \\
\end{array}$ & Ket. \\
\hline Zona A (pot. 5-5) & 0.595 & $<$ & 1.25 & $\begin{array}{c}\text { Butuh } \\
\text { Perkuatan }\end{array}$ \\
\hline Zona B (pot. 4-4) & 1.177 & $<$ & 1.25 & $\begin{array}{l}\text { Butuh } \\
\text { Perkuatan }\end{array}$ \\
\hline Zona C (pot. 3-3) & 1.172 & $<$ & 1.25 & $\begin{array}{c}\text { Butuh } \\
\text { Perkuatan }\end{array}$ \\
\hline Zona D (pot. 2-2) & 0.853 & $<$ & 1.25 & $\begin{array}{c}\text { Butuh } \\
\text { Perkuatan }\end{array}$ \\
\hline $\begin{array}{l}\text { Zona D (pot. 1-1) } \\
\text { didalam wing- } \\
\text { wall }\end{array}$ & 1.124 & $<$ & 1.25 & $\begin{array}{c}\text { Butuh } \\
\text { Perkuatan }\end{array}$ \\
\hline
\end{tabular}

- Perkuatan Timbunan Oprit Berisi Miring (Alternatif Perkuatan Geotextile untuk Oprit bersisi Miring)

Geotextile digunakan Woven geotextile 200/45 produk Stabilenka. Dimana untuk masing-masing hasil output SF kritis stabilitas timbunan dari dxstable perpotongan zoning oprit dihitung kebutuhan jumlah layer terbanyak untuk dapat mencapai MR rencana. persamaan sebagai berikut:

$$
\begin{aligned}
& L=S v+L_{o}+L_{e}+L_{d} \\
& \mathrm{~Sv}=25 \mathrm{~cm} \\
& L_{e}=\frac{T_{\text {Allow }} \times F S}{(\tau 1+\tau 2) \times E}
\end{aligned}
$$

$\mathrm{Ld}=$ panjang geotextile melewati bid.longsor.

Kestabilan geotextile juga dikontrol terhadap 3 kondisi dengan persamaan sebagai berikut:

$$
P a 1 \leq \frac{-\quad \begin{array}{c}
((\text { Berat ernal Stability: } \\
\mathrm{ABC} \times \tan \delta))
\end{array}}{S F}
$$

(Tanpa ada Geotextile)

$P a 1 \leq \frac{(\text { Berat efektif } \mathrm{ABC} \times \tan \delta)}{S F}+T$. Allow

$$
\begin{gathered}
\text { - Overall Stability: } \\
S F=\frac{M \cdot \text { penahan }}{M \cdot \text { pendorong }}=\frac{\text { MR.eksisting }+\Delta M R \cdot \text { rencana }}{M \cdot \text { Pendorong }}>1,5
\end{gathered}
$$

$$
\begin{gathered}
\text { Foundation Stability: } \\
P a \leq \frac{P P+(2 \times(2 / 3 \times C u) \times L)}{S F}
\end{gathered}
$$

\begin{tabular}{|c|c|c|c|c|}
\hline Zoning Oprit & $\begin{array}{l}\text { H Final } \\
(\mathrm{m})\end{array}$ & $\begin{array}{l}\mathrm{H} \text { initial } \\
(\mathrm{m})\end{array}$ & $\begin{array}{c}\text { Reinforc } \\
\text { ement }\end{array}$ & $\begin{array}{l}\text { Total } \\
\text { Layer }\end{array}$ \\
\hline Zona A (pot. 5-5) & 3 & 4.457 & $\begin{array}{l}\text { GW* } \\
200 / 45\end{array}$ & 7 layer \\
\hline Zona B (pot. 4-4) & 6 & 8.304 & $\begin{array}{c}\text { GW } \\
200 / 45\end{array}$ & 7 layer \\
\hline Zona C (pot. 3-3) & 9 & 11.757 & $\begin{array}{c}\mathrm{GW} \\
200 / 45\end{array}$ & $\begin{array}{c}21 \\
\text { layer }\end{array}$ \\
\hline Zona D (pot. 2-2) & 10.459 & 13.390 & $\begin{array}{c}\text { GW } \\
200 / 45\end{array}$ & $\begin{array}{c}33 \\
\text { layer }\end{array}$ \\
\hline $\begin{array}{l}\text { Zona D (pot. 1-1) } \\
\text { didalam wing-wall }\end{array}$ & 10.659 & 12.757 & $\begin{array}{c}\text { GW } \\
200 / 45\end{array}$ & $\begin{array}{c}39 \\
\text { layer }\end{array}$ \\
\hline
\end{tabular}

$$
P a \leq \frac{P P+(2 \times(2 / 3 \times C u) \times L)}{S F}+T . \text { Allow }
$$

(ada Geotextile)

Didapatkan hasil dari perhitungan yang aman untuk masing-masing zoning seperti yang ditunjukkan pada Tabel 7:

Tabel 7. Rekap Kebutuhan Geotextile Oprit berisi Miring

\begin{tabular}{|c|c|c|c|}
\hline Zoning Oprit & Reinfocement & Total (2 oprit) & $\begin{array}{c}\text { Depth } \\
(\mathrm{m})\end{array}$ \\
\hline Zona A (pot. 5-5) & $\begin{array}{c}\mathrm{MP}^{*} \\
30 \mathrm{~cm} \times 30 \mathrm{~cm}\end{array}$ & $\begin{array}{l}2 \times 13 \text { pcs per- } \\
\text { meter longt.* }\end{array}$ & 3 \\
\hline Zona B (pot. 4-4) & $\begin{array}{c}\text { MP } \\
30 \mathrm{~cm} \times 30 \mathrm{~cm}\end{array}$ & $\begin{array}{l}2 \times 19 \text { pcs per- } \\
\text { meter longt. }\end{array}$ & 3 \\
\hline Zona C (pot. 3-3) & $\begin{array}{c}\text { MP } \\
30 \mathrm{~cm} \times 30 \mathrm{~cm}\end{array}$ & $\begin{array}{c}2 \times 29 \text { pcs per- } \\
\text { meter longt. }\end{array}$ & 6 \\
\hline Zona D (pot. 2-2) & $\begin{array}{c}\text { MP } \\
30 \mathrm{~cm} \times 30 \mathrm{~cm}\end{array}$ & $\begin{array}{c}2 \times 25 \text { pcs per- } \\
\text { meter longt. }\end{array}$ & 6 \\
\hline $\begin{array}{l}\text { Zona D (pot. 1-1) } \\
\text { didalam wing-wall }\end{array}$ & $\begin{array}{c}\text { MP } \\
30 \mathrm{~cm} \times 30 \mathrm{~cm} \\
\end{array}$ & $\begin{array}{l}2 \times 25 \text { pcs per- } \\
\text { meter longt. }\end{array}$ & 6 \\
\hline
\end{tabular}

* $\mathrm{GW}=$ Geotextile Woven

- Perkuatan Timbunan Oprit Berisi Miring (Alternatif

Perkuatan Geotextile untuk Oprit bersisi Miring)

Digunakan micropile dengan dimensi $30 \mathrm{~cm}$ x $30 \mathrm{~cm}$ dengan mutu beton $30 \mathrm{MPa}$ dan penulangan 4-D16. Didapatkan hasil perhitungan untuk masing-masing zoning seperti yang ditunjukkan pada Tabel 8:

Tabel 8. Rekap Kebutuhan Micropile oprit berisi miring

\section{Perencanaan Biaya Material Timbunan}

- Perhitungan Biaya Alternatif Timbunan Berisi Tegak Untuk timbunan oprit bersisi tegak dapat dibandingkan biaya antara alternatif geotextile kombinasi flat sheet-pile dan alternatif geogrids kombinasi keystone-wall dengan perbandingan biaya sebagai berikut:

- Rekap total biaya timbunan oprit bersisi tegak dengan perkuatan alternatif geotextile kombinasi flat sheetpile dengan total biaya Rp.86,280,857,674.34.

- Rekap total biaya timbunan oprit bersisi tegak dengan perkuatan alternatif geogrids kombinasi keystonewall dengan total biaya Rp.73,797,613,851.84

- Perhitungan Biaya Alternatif Timbunan Berisi Miring Untuk timbunan oprit bersisi miring dapat dibandingkan biaya antara alternatif geotextile dan alternatif micropile dengan perbandingan biaya sebagai berikut:

- Rekap total biaya timbunan oprit bersisi miring dengan perkuatan alternatif geotextile dengan total biaya Rp.103,183,365,174.93 
- Rekap total biaya timbunan oprit bersisi miring dengan perkuatan alternatif micropile dengan total biaya Rp.134,243,009,394.93

\section{E. Perencanaan Abutment}

Data jembatan adalah sebagai berikut:
Panjang girder (L)
$=30 \mathrm{~m}$
Lebar jalan (b)
$=2 \times 14 \mathrm{~m}$
Lebar Trotoar
$=4 \times 0.5 \mathrm{~m}$
Tebal Trotoar
$=0.5 \mathrm{~m}$
Tebal plat lantai jembatan $\left(\mathrm{t}_{\mathrm{s}}\right) \quad=0.25 \mathrm{~m}$
Tebal lapisan aspal + overlay $\left(\mathrm{t}_{\mathrm{a}}\right)=0.1 \mathrm{~m}$
Lebar abutment (B)
Tinggi abutment (ha)
$=32.725 \mathrm{~m}$
$=12.529 \mathrm{~m}$

Sketsa potongan melintang jembatan ditunjukkan pada Gambar 3:

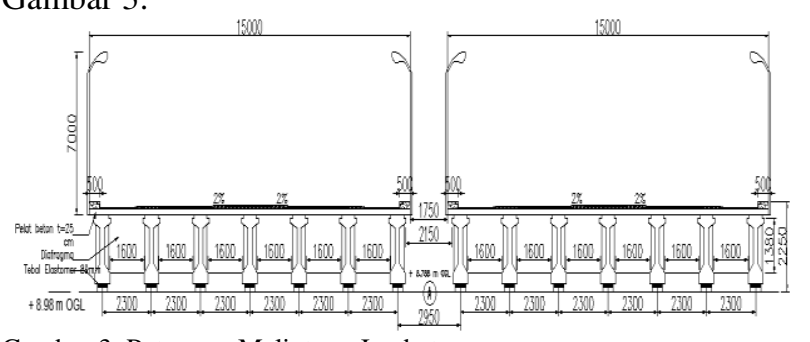

Gambar 3. Potongan Melintang Jembatan.

Direncanakan abutment seperti yang ditunjukkan pada Gambar 4:

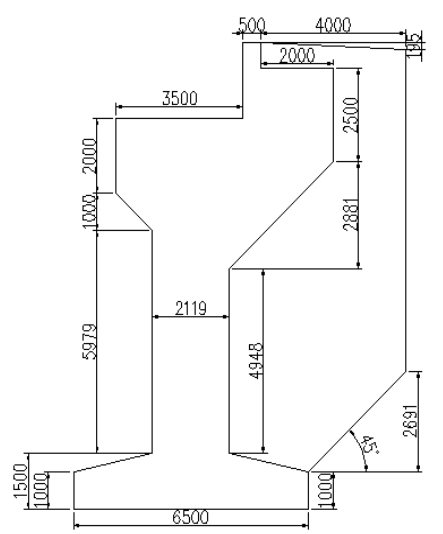

Gambar 4. Rencana abutment.

Dengan rekap kombinasi pembebanan seperti yang ditunjukkan pada Tabel 9:

Tabel 9. Rekap Kombinasi Pembebanan pada Abutment

\begin{tabular}{|c|c|c|c|c|c|}
\hline \multirow{2}{*}{$\begin{array}{c}\text { Kombinasi } \\
\text { Pembebanan }\end{array}$} & \multicolumn{3}{|c|}{ Gaya (ton) } & \multirow{2}{*}{$\begin{array}{c}\text { momen-x } \\
(\mathrm{t}-\mathrm{m})\end{array}$} & \multirow{2}{*}{$\begin{array}{c}\text { momen-y } \\
(\mathrm{t}-\mathrm{m})\end{array}$} \\
\hline & $\mathrm{Hx}$ & Hy & $\mathrm{V}$ & & \\
\hline Kombinasi 1 & 2260,66 & 0 & 5631,78 & 0 & 5825,81 \\
\hline Kombinasi 2 & 2264,99 & 0 & 5631,78 & 0 & 5871,2 \\
\hline Kombinasi 3 & 2260,66 & 6,51 & 5631,78 & 75,62 & 5825,81 \\
\hline Kombinasi 4 & 2264,99 & 6,51 & 5631,78 & 75,62 & 5871,2 \\
\hline Kombinasi $5 \mathrm{X}$ & 6641,6 & 433,56 & 5157,74 & 3074,71 & 38689,94 \\
\hline Kombinasi $5 \mathrm{Y}$ & 3539,94 & 1445,19 & 5157,74 & 10249,04 & 15326,37 \\
\hline
\end{tabular}

Kontrol stabilitas abutment tanpa ada pondasi dalam:

- Dalam keadaan masa layan diperiksa kestabilan geser \& guling menurut ps.11 RSNI T-02 2005 ; menunjukkan stabilitas abutment tidak aman.

- Dalam keadaan masa konstruksi diperiksa kestabilan terhadap geser, guling, dan amblas ; menunjukkan stabilitas abutment tidak aman.

Dikarenakan kontrol stabilitas abutment tidak aman, maka abutment membutuhkan pondasi dalam berupa tiang pancang.

\section{F. Perencanaan Pondasi Dalam}

Dihitung daya dukung tanah untuk PC Spun pile diameter $60 \mathrm{~cm}$ dengan metode Mayerhoff \& Bazaraa per-data DB 01 \& DB-02. Direncanakan grup tiang pancang seperti yang ditunjukkan pada Gambar 5:

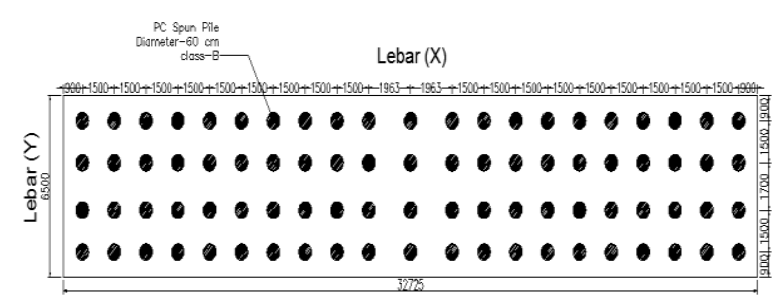

Gambar 5. Konfigurasi Tiang Pancang Abutment.

Tiang pancang digunakan produk PT. Waskita Precast PC Spun Pile Class = B

Kedalaman Pancang $=42 \mathrm{~m}$ (dari OGL) Jumlah Tiang pancang $=84$ buah

\section{G. Penulangan Abutment}

Rekap hasil perhitungan penulangan abutment seperti yang ditunjukkan pada Tabel 10:

\begin{tabular}{lcccccc}
\multicolumn{7}{c}{ Tabel 10. Rekap Penulangan abutment } \\
\hline \multirow{7}{*}{ Penulangan } & \multicolumn{5}{c}{ Jumlah - Diameter - Jarak } \\
& 220 & D22 & 148 & 12 & D19 & 453 \\
\hline Plat Injak & 124 & D22 & 261 & 8 & D19 & 222 \\
Back Wall & 62 & D25 & 62 & 46 & D22 & 243 \\
Wing Wall & 402 & D32 & 81 & 48 & D22 & 185 \\
Breast Wall & 452 & D32 & 72 & 52 & D19 & 121 \\
Pile Cap & 42 & & & & & \\
\hline
\end{tabular}

\section{KESIMPULAN}

Dalam perencanaan studi ini telah diperoleh kesimpulan sebagai berikut:

1. Berdasarkan alternatif perencanaan timbunan oprit fly over Kandangan dimana direncanakan antara oprit bersisi tegak dan oprit bersisi miring. Diperoleh perencanaan tinggi timbunan awal $(\mathrm{H}$ initial) yang dibutuhkan untuk mencapai tinggi timbunan akhir $(\mathrm{H}$ final) yang direncanakan serta besar consolidation settlement yang akan terjadi. Telah dijelaskan pada Tabel 3.2 dan Tabel 3.6.

2. Perhitungan pemampatan konsolidasi alami disimpulkan bahwa waktu yang dibutuhkan untuk menghilangkan consolidation settlement sangat lama yaitu 222 tahun dan sisa consolidation settlement dari umur rencana ini bisa mengakibatkan rusaknya perkerasan oprit. Sehingga diputuskan Untuk mempercepat proses konsolidasi (Uv $=90 \%)$ dan Mempercepat peningkatan daya dukung tanah dasar diperlukan pemasangan PVD serta PHD untuk pengalir air pori dari PVD.

3. Diperoleh hasil bahwa pola pemasangan PVD segi empat dengan spasi antar PVD 0,8 $\mathrm{m}$ adalah yang paling efektif dengan waktu konsolidasi yang di ijinkan 24 Minggu (masa efektif PVD). Dengan kebutuhan installasi PVD untuk masing-masing alternatif perencanaan oprit telah dijelaskan dalam pembahasan diatas.

4. Berdasarkan analisa kestabilan lereng oleh karena peningkatan daya dukung tanah dasar setelah selesai masa penimbunan $\mathrm{H}$-initial untuk masing-masing 
alternatif timbunan oprit. Untuk kestabilan timbunan oprit bersisi tegak \& miring telah dijelaskan pada tabel $3.3 \&$ tabel 3.7.

5. Perencanaan perkuatan timbunan pada oprit bersisi tegak direncanakan dengan 2 alternatif. Dengan diperoleh kesimpulan total biaya variabel secara pendekatan (+ PPN 10\%) untuk alternatif perkuatan geotextile kombinasi flat sheet-pile adalah $\mathrm{Rp}$. 86.280.857.674,34 dan untuk alternatif perkuatan geogrids kombinasi keystone-wall adalah $\mathrm{Rp}$. 73.797.613.851,84. Sehingga disimpulkan untuk oprit bersisi tegak dengan perkuatan geogrids kombinasi keystone-wall yang lebih murah.

6. Perencanaan perkuatan timbunan pada oprit bersisi miring direncanakan dengan 2 alternatif. Dengan diperoleh kesimpulan total biaya variabel secara pendekatan (+ PPN 10\%) untuk alternatif perkuatan geotextile adalah Rp. 103.183.365.174,93 dan untuk alternatif perkuatan micropile adalah $\mathrm{Rp}$. 134.243.009.394,93 Sehingga disimpulkan bahwa untuk oprit bersisi miring dengan perkuatan geotextile yang lebih murah.

7. Berdasarkan perhitungan total biaya yang dibutuhkan oleh alternatif perencanaan timbunan oprit, maka dipilih alternatif timbunan dan perkuatan yang paling efektif dari segi biaya, pelaksanaan, dan hemat ruang sehingga oprit bersisi tegak dengan perkuatan geogrids kombinasi keystone-wall adalah yang paling sesuai. Dengan total biaya Rp. 73.797.613.851,84.

8. Abutment direncanakan dengan lebar melintang $32,725 \mathrm{~m}$ dan tinggi total $12,530 \mathrm{~m}$ dengan $-1.50 \mathrm{~m}$ dari OGL. Dimensi pilecap 32,725 m x 6,5 m.
9. Pondasi dalam dipakai tiang pancang PC Spun Pile produk PT.Waskita Precast diameter $60 \mathrm{~cm}$ berjumlah 84 buah dengan dipancang kedalaman $42 \mathrm{~m}$ dari OGL.

\section{DAFTAR PUSTAKA}

[1] Das, M. Braja., Mekanika Tanah 1 (Prinsip-Prinsip Rekayasa Geoteknis), Erlangga, Jakarta, 1985.

[2] Das, M. Braja., Mekanika Tanah 2 (Prinsip-Prinsip Rekayasa Geoteknis), Erlangga, Jakarta, 1985.

[3] Das, Braja M. Mekanika Tanah I: Prinsip-Prinsip Rekayasa Geoteknik. Diterjemahkan oleh Noor Endah dan Indrasurya B.M. Surabaya: Erlangga, 1988.

[4] Das, M. Braja.,'Principles of Foundation Engineering, second edition", Brooks Cole, 1990.

[5] Departemen Pekerjaan Umum., Modul Pengantar dan PrinsipPrinsip Perencanaan Bangunan Bawah/Pondasi Jembatan, Indonesia. 1988.

[6] Hansbo, S., "Consolidation of Clay by Band-Shaped Prefabricated Drains", Ground Engineering, Vol.12,No.5.pp.21$25,1979$.

[7] Mochtar, Noor E., "Modul Ajar Metode Perbaikan Tanah", Jurusan Teknik Sipil FTSLK - ITS, Surabaya: ITS PRESS, 2012.

[8] Mochtar, Indrasurya B, "Teknologi Perbaikan Tanah dan Alternatif Perencanaan pada Tanah Bermasalah (Problematic Soils)", Jurusan Teknik Sipil FTSLK - ITS.

[9] Muntohar, Agus S., Jembatan, cetakan edisi-IV, Beta offset, Yogyakarta,2007.

[10] NAVFAC DM-7., "Design Manual, Soil Mechanics, Foundation and Earth Structure", Dept of the Navy Naval Facilities Engineering Command, Virginia, USA, 1970.

[11] Pedoman Konstruksi dan Bangunan Pd-T-11-2003., Perencanaan Timbunan Jalan Pendekat Jembatan, Indonesia, 2003.

[12] Terzaghi, Karl dan B. Peck, Ralph, Mekanika Tanah Dalam Praktek Rekayasa, Erlangga, Jakarta, 1993.

[13] Wahyudi, Herman. Daya Dukung Pondasi Dangkal. Jurusan Teknik Sipil FTSLK - ITS Surabaya, 1999. 